\title{
RESET
}

Recherches en sciences sociales sur Internet

$7 \mid 2018$

Formes et mouvements politiques à l'ère numérique

\section{Political Forms and Movements in the Digital Era}

\section{Clément Mabi and Célya Gruson-Daniel}

\section{(2) OpenEdition \\ Journals}

Electronic version

URL: http://journals.openedition.org/reset/1094

DOI: 10.4000/reset.1094

ISSN: 2264-6221

\section{Publisher}

Association Recherches en sciences sociales sur Internet

\section{Electronic reference}

Clément Mabi and Célya Gruson-Daniel, «Political Forms and Movements in the Digital Era », RESET

[Online], 7 | 2018, Online since 29 October 2018, connection on 19 April 2019. URL : http:// journals.openedition.org/reset/1094; DOI : 10.4000/reset.1094

This text was automatically generated on 19 April 2019

(c) Association Recherches en sciences sociales sur Internet 


\title{
Political Forms and Movements in the Digital Era
}

\author{
Clément Mabi and Célya Gruson-Daniel
}

1 Digital technologies are progressively emerging as a major political resource. The renewal in communication forms transforms media, traditional institutions and the structuring dynamics of the political arena, like the opposition or the expression of alternative ideas. Mobilized in a wide variety of situations, they have become both an essential element in the toolkit of field actors and a mandatory component of discourses regarding the transformation of democracy and public space. That omnipresence, which has almost become a matter of evidence as it is seldom discussed, is rarely paralleled by a rigorous definition of what the "digital" is and by precise descriptions of the realities it covers. This phenomenon leads to obscuring the diversity of the political, social and technical projects it encompasses. Composed of a series of "black boxes", it is often questioned through its uses, without reflecting seriously on the symbolic dimension of technical choices and their influence on practices. The ambition of this issue of the RESET journal is indeed to question how digital technologies, embedded in different contexts, produce new forms of political mobilization and organization, or stabilize older ones, while conveying multiple values and principles which are, in turn, transforming technologies themselves.

In academic literature, many works have focused on the renewal of collective action repertoires and have described the new forms of citizenship and activism they entail (Downing, 2000; Norris, 2001; Cardon \& Granjon, 2013; Mabi \& Theviot, 2014b, Granjon et al, 2017). They rely on research dealing with "online political participation" (MonnoyerSmith \& Wojcik, 2014), gradually overcoming the dichotomy between "cyber-optimists" (Castells, 2012) and "cyber-pessimists" (Morozov, 2011) to propose a "differentiated" approach focused on the change in repertoires of action and commitment forms engendered by the use of digital tools to "discuss politics" (Monnoyer-Smith, 2011; Mossberger, Tolbert \& McNeal, 2007). This perspective, which highlights the link between the evolutions of cultural practices and the reasons of political commitment, allows to 
apprehend the weight of the sociotechnical environment in the variety of forms of citizen mobilization.

Depending on the tools available to them, repertoires of actions evolve and enable various forms of expression. Thus, the principles of participation, collaboration, networking or "commoning", considered as constitutive of the digital culture (Deuze, 2006; Jenkins, 2006), influence the ways in which citizens position themselves in public spaces and perceive their citizenship. The forms of commitment allowed by digital technologies construct a specific relationship with politics, anchored in self-organized means of expression, overcoming traditional representations (Cardon \& Granjon, 2013). Citizens now have the opportunity to connect and organize to implement collective projects without going through the usual forms of organization such as the market and the State (Bimber and Flanagan 2005, Granjon et al 2017). Thus, the proliferation of digital technologies offers individuals a renewed ability to act. It moves democracy's gravity center and places a greater emphasis on "multitudes" (Cardon, 2010). This logic gradually leads to a shift in democratic legitimacy, moving from the work of institutions to the result of conversations among citizens, and through more or less creative forms (Monnoyer-Smith, 2011, Cardon, 2015). Among these forms of action, new demands emerge, such as the governance of commons by the citizens themselves. These are accompanied by new forms of vigilance of the democratic processes related to the notion of transparency and openness of public data, characterized by the recent development of open data movements (Denis and Goëta, 2017), but also civic tech (Mabi, 2017) and citizen hacking (Schrock, 2016). These participative commitments also invest digital social networks with, for example, the mobilization of opinion around hashtags (Badouard, 2017). But behind the apparent openness brought by these opportunities of digital citizen participation, other studies also suggest that online participation remains embedded in social (traditional) logics, such as the size of the cities in which citizens live (Parasie and Cointet, 2012), that is far beyond the scope of technologies.

4 This issue of RESET aims to question these practices of participation in the "digital age", and more generally the contemporary reconfigurations of our relationship with politics through the evolution of our sociotechnical environment. Is this new freedom offered by the digital devices mobilized to "make polity" differently? Does the inrush of multitudes in the public area contribute to transform or overcome the traditional militant commitment anchored in organizations? To what extent can these new forms of engagement be seen as "participation" and political activity? How are the concepts of self-organization, collective emancipation or agency put to the test?

5 The three articles in this RESET issue seek to provide some answers to these questions and illustrate the importance of an "ecological" approach to digital tools (Badouard et al, 2016). In this case, the political scope of digital technologies is taken into account, as well as the heterogeneity of the contexts in which they are embedded. This approach reminds us that digital technologies are only one of the variables to be analyzed in order to grasp the complexity of power relations. It highlights how the construction of meaning is based on values, tested by activities, that are in turn mediated by these sociotechnical devices. Thus, rather than affirming that the digital world is political and a priori favorable to participation, or to a transformation of democracy and the public space, we need to better take into account its ambivalence in this regard. In order to analyze the political sense that technologies take in situation, the focus should be on the importance of "descripting" technical objects ${ }^{1}$. The challenge here is to consider the technical object as a 
mediator, the entry point into social relations to articulate an understanding of the logic of action on one side and the construction of technologies on the other - i.e., on one hand, how technology affects practices, and on the other hand, what practices imply for the construction of technologies. In this perspective, the technological construction of the social - that is, the capacity of technologies to participate in the production of the social - take center stage. In fact, technologies are not at the center of the analysis, which focuses on what the actors do with the technologies. On this point, the work of Jérôme Denis (2018) and Bernard Conein (2005) is enlightening, by inviting to follow processes, to draw threads without lending an excessive rationality to the actors, and to do justice to the heterogeneity of the social. This focus on the trajectories of objects and actors allows us to think of how objects perform society, culture and of course politics. In this complex and dynamic ecology that forms the social, we know (since Michel Foucault's pioneer work) that politics can nestle in the smallest details of everyday life, and these are extremely heterogeneous. The exchanges are not "fluid" and share a set of constraints that endow actors' choices with a certain symbolic value. By analyzing the political scope of technologies, this issue of the RESET journal aims to accurately account for the capabilities of these technologies to influence the collective construction of the social. Based on concrete cases, the three articles help to question the political significance of different forms of organization and militant or partisan mobilization, and their ability to experiment with new ways of "making polity".

6 Thus, Hadrien Macq and Vincent Jacquet's article "To engage in a cyberparty: Internet in the Belgian Pirate Party Membership" questions the ability of digital tools to enhance commitment forms within a partisan organization. The authors' aim is to better understand how the use of the Internet is changing traditional activism by incorporating particular representations of the relationship between technology and society (decentralized management of decisions, customized commitment, etc.). Beyond the ideal-type of the cyber-activist, two major figures emerge from their investigation: technical activists and relational activists. The first are generally from communities related to the digital world. They are committed to improve the functioning of representative democracy by mobilizing the resources offered by digital tools. Their political objective is to help prepare the society for digital-fostered change (management of commons, evolution in copyright). As for the second type of activists, authors show that their commitment to the Pirate Party is based on the belief that the Pirates are likely to propose a democratic innovation that could radically transform the functioning of democracy and the citizen's place in it through more horizontal interactions. One of the main results of the article is to show that these new parties are a support for commitments, with more varied motivations than dominant discourses would suggest.

7 The article by Anaïs Theviot and Eric Treille "Civic tech to the test of political parties. Participatory Platforms of the Union for Popular Movement (UMP) and the Socialist Party (PS)", on the contrary, questions the evolutions of traditional partisan structures. Is it possible to institutionalize self-organized forms of participation, typical of digital public spaces? Their investigation of the way in which the two major French parties attempted to copy emerging initiatives to "provide new ideas" illustrates the difficulty of this type of approach. It accounts for a scenario of "deception" on the Internet, where the ideals of pioneers do not necessarily translate into practices. The two researchers deconstruct the accompanying discourse produced by parties to better observe the resilience of organizations and their desire to preserve their organization and control of their 
communication. The example of the Socialist Party's activist social network, La Coopol, illustrates this point. After Ségolène Royal's experimentation with "Désir d'Avenir", the PS tries once again to reduce the gap between activists and supporters. Thus, an online platform seems to have different audiences meeting and exchanging, sometimes far from conventional institutions. However, the survey shows that the initiative will not be able to reach, to a large extent, an audience of members away from expected supporters.

The article by Diego-Antolinos-Basso, Flaminia Paddeu, Nicolas Douay and Nathalie Blanc "Why has the debate on \#EuropaCity not taken place on Twitter? Analysis of the mobilization around an environmental controversy on the social network" proposes a survey of digital uses in mobilizations around the environmental controversy concerning the project of commercial complex in Val d'Oise Europa City. This study aims to question the exchanges around the project on the social network to analyze the transformations of environmental citizenship. Through a discussion of the literature on the relations between social movements and digital tools, and particularly on the ability of social networks to propose an alternative arena for counter-publics to value specific aspects of their speech, the authors seek to explain why, ultimately, the controversy has struggled to exist on Twitter. Do social networks really have the capacity to correct asymmetries of resources and power? Can they, alone, sustain online a debate which is locked offline? The major result of this research is to show the interweaving of different arenas. It emphasizes the need to think about extensions and circulations between online and offline spaces. The spatial dimension of the mobilizations and their territorial anchoring remains a major factor in the construction of public concerns.

Reflecting on these three articles at once allows to highlight several cross-cutting results. First, there is a the need to go back to the definition of the "digital" adjective - which in the French language, is also a noun that can refer to the digital world as a whole, with its practices, technologies and actors. This word, as well as other expressions such as civic tech, openness or commons, can be used to assert different representations of politics or democracy today.

10 The three case studies also contribute to the demystification of digital technologies and highlight the social diversity of the political relations they cover. Whether it is in the organization of a cyber-party, in the attempts to establish a controversy on Twitter, or in the creation of a new partisan platform, these studies show that the production of symbolic goods is the result of a co-construction between the technical resources and the way in which actors seize them, paving the way for a large variety of configurations. The article by Hadrien Macq and Vincent Jacquet, by introducing the technical and relational ideal-types of activists, illustrates this point well. Relational profiles tend to view digital devices as a support for creating new and more horizontal democratic processes, to become the foundation of another societal model, where technical profiles view technologies as a resource for transforming existing institutions by improving their effectiveness. The article by Anaïs Theviot and Eric Treille notes that in the case of a platform with participatory design supposed to favor the contribution of a public of sympathizers, larger than the circle of usual members, the technologies are thought of as a tool of political campaigning, in the continuity of traditional and advocacy partisan repertoires which provide little to no incentive to individuals beyond militant circles.

11 The articles also show the importance of taking "technological solutionism", too often thought of as the digital answer to the problems of democracy, with a grain of salt. Indeed, it often leads to relativize the political weight of arenas equipped by digital 
technologies and their difficulty to transform sustainably power relations with institutions. The three studies show us that technologies alone are not enough to embody a project of social transformation or democratic renewal. Thus, the article by Diégo Antolinos-Basso and his colleagues illustrates this point by showing that, even if the stakeholders involved in the \#EuropaCity debate consider Twitter as a space of expression for an alternative speech, this condition is not enough to give life to this controversy and to put forward alternative points of view, outside traditional communication channels.

More broadly, the three articles bring into question the resilience of institutions and their ability to establish themselves as a key player in any social transformation project. The article on partisan civic tech, in particular, accounts for the endurance of political parties' organizational logics, which eventually exclude the "sympathizers" who are targeted at the beginning of the experience. In this context, the call for digital technologies and their participatory vocabulary does not, ultimately, challenge any balance of power at its core. The digital world is therefore a resource for political entities that explore the tensions between democratic experimentation and resistance of organizations.

\section{BIBLIOGRAPHY}

AKRICH Madeleine (1997). « Les utilisateurs, acteurs de l'innovation », Éducation permanente, (134), pp. 79-90.

BADOUARD Romain (2017). Le désenchantement de l'Internet: désinformation, rumeur et propagande. Limoges, Fyp.

BADOUARD Romain, MABI Clément \& MONNOYER-SMITH Laurence (2017). « Le débat et ses arènes : À propos de la matérialité des espaces de discussion », Questions de communication, (30), pp. 7-23.

Bimber Bruce, flanagin Andrew J. \& STOHL Cynthia (2005). « Reconceptualizing Collective Action in the Contemporary Media Environment », Communication Theory, 15 (4), pp. 365-388.

CARDON Dominique (2010). La démocratie Internet : promesses et limites. Paris, Seuil.

CARDON Dominique (2015). A quoi rêvent les algorithmes: nos vies à l'heure des big data. Paris, La

République des idées : Seuil.

CARDON Dominique \& GRANJON Fabien (2013). Médiactivistes. Paris, Sciences po, les presses.

CASTELLS Manuel (2012). Networks of outrage and hope: social movements in the Internet Age.

Cambridge, UK ; Malden, MA, Polity Press.

CONEIN Bernard (2005). Les sens sociaux: trois essais de sociologie cognitive. Paris, Economica.

DENIS Jérôme (2018). Le travail invisible des données : éléments pour une sociologie des infrastructures scripturales. Paris, Presses des Mines.

DEUZE Mark (2006). « Collaboration, participation and the media », New Media \& Society, 8 (4), pp. 691-698. 
DOWNING John (2001). Radical Media: Rebellious Communication and Social Movements. Thousand Oaks, CA, Sage.

ERMOSHINA Ksenia (2017). « Le code peut-il réparer les routes? », Réseaux, (206), pp. 155-189.

GRANJON Fabien (2017). Mobilisations numériques : Politiques du conflit et technologies médiatiques.

Paris, Presses des Mines.

JENKINS Henry (2008). Convergence culture: where old and new media collide. New York, NY, New York Univ. Press.

MABI Clément (2017). «Citoyen hackeur », La Vie des idées.

MABi Clément \& THEVIot Anaïs (2014). «Présentation du dossier », Politiques de communication, (3), pp. 5-24.

MONNOYER-SMITH Laurence (2011). Communication et délibération enjeux technologiques et mutations citoyennes. Paris, Lavoisier.

MONNOYER-SMITH Laurence \& WOJCIK Stéphanie (2014). « La participation politique en ligne, vers un renouvellement des problématiques? », Participations, (1), pp. 5-29.

MOROzov Evgenij V. (2011). The net delusion: the dark side of internet freedom. New York, NY, Public Affairs.

MOSSBERGER Karen, TOLBERT Caroline J. \& MCNEAL Ramona S. (2008). Digital citizenship: the internet, society, and participation. Cambridge, Mass, MIT Press.

NORRIS Pippa (2003). «Preaching to the converted?: Pluralism, participation and party websites », Party Politics, 9 , pp. 21-45.

PARASIE Sylvain \& COINTET Jean-Philippe (2012). « La presse en ligne au service de la démocratie locale, The online press role in local democracy. A morphological analysis of political forums in France ", Revue française de science politique, 62 (1), pp. 45-70.

SCHROCK Andrew R. (2016). « Civic hacking as data activism and advocacy: A history from publicity to open government data ", New Media \& Society, 18 (4), pp. 581-599.

\section{NOTES}

1. See on this point Madeleine Akrich's founding article (1998) and Ksenia Ermoshina's work (2018)

\section{AUTHORS}

\section{CLÉMENT MABI}

Université de Technologie de Compiègne, $\mathrm{COSTECH}$ 


\section{CÉLYA GRUSON-DANIEL}

Université de Technologie de Compiègne, COSTECH et Université Paris-Descartes, CRI 